\title{
The Impact of Predation Risk on the Marginal Value of Cash Holdings: An Empirical Perspective
}

\author{
Xinbao Yang, Jiguang Zheng* \\ Fudan Development Institute, Fudan University, Shanghai, China \\ Email:759226975@qq.com, *jigzheng@foxmail.com
}

How to cite this paper: Yang, X. B., \& Zheng, J. G. (2017). The Impact of Predation Risk on the Marginal Value of Cash Holdings: An Empirical Perspective. Journal of Financial Risk Management, 6, 150162 .

https://doi.org/10.4236/jfrm.2017.62012

Received: May 12, 2017

Accepted: June 16, 2017

Published: June 19, 2017

Copyright $\odot 2017$ by authors and Scientific Research Publishing Inc. This work is licensed under the Creative Commons Attribution International License (CC BY 4.0).

http://creativecommons.org/licenses/by/4.0/

\begin{abstract}
As an important external governance mechanism, product market competition has considerable impact on the marginal value of a company's cash holdings in various aspects. This paper examines the impact of predatory risk on the marginal value of cash holdings in product market by sampling Chinese A-share listed companies from 2000 to 2013. It shows that the predation risk in the product market increases the marginal value of cash holdings by 0.2 Yuan.
\end{abstract}

\section{Keywords}

Predation Risk, Stock Excess Returns, Marginal Value, Cash Holdings

\section{Introduction}

It has been widely recognized that the product market competition has a farreaching impact on important financial policies of a company. Various scholars have achieved fruitful results from different research aspects via endlessly strives. Many of their research focus on the interaction between the product market competition and capital structure. In recent years, with a rising in corporate cash holdings, scholars have gradually shifted their research perspectives. Nevertheless, Cash holdings play as one of the central role in the research of corporate finance. After the global financial crisis in 2008, the issue of cash holdings reappeared to be a hotspot of academic research. Cash holdings can help a company to cope with the shocks of unfavorable exogenous events, as well as to seize the favorable investment opportunities.

At present, most scholars study the issue of cash holdings from the company's characteristics, corporate governance and so on. And there is a small number of 
scholars do research by considering the external business environment, such as product market competition. However, in our first understanding, there is no existing study on the impact of the product market competition on the marginal value of a company's cash holdings. Different from the previous literatures that study the marginal value of cash holdings from the microcosmic perspective of the internal characteristics of the company or the macro-level of the state institutions, the paper is based on the company's meso-level environment, and explores how the product market threat affect a company's marginal value of cash holdings, and further to expand the research depth and breadth.

The rest of the article is arranged as follows: Section 2 provides a brief literature review and theoretical analysis. Section 3 introduces a structure of empirical study, and Section 4 provides empirical analysis. The last section concludes and provides two directions for future research.

\section{Literature Review}

Bates et al. (2017) find that the value of cash holdings by U.S. non-financial firms has increased significantly over the past three decades. Meanwhile, more and more academic research focus on the relation between product market competition and cash holdings. We summarize the previous research from two aspects.

\subsection{Product Market Competition, Agency Confliction and Cash Utilization Efficiency}

As a kind of external governance mechanism, the product market has the dual function of information mechanism and restraint mechanism. On the one hand, the product market competition can provide the performance comparison standard for the external investors. Since the enterprises are influenced by the market fluctuation simultaneously, if there are many enterprises on the market, the performance between the enterprises is comparatively comparable. Therefore the investors can easily identify the personal ability and effort lever of different managers, thus reducing the information asymmetry and supervision costs, and thus to some extent inhibit the management of the company's free cash flow, improve the efficiency of the use of cash. On the other hand, competition in the product market increases the probability of corporate losses and bankruptcy liquidation, which puts greater internal pressure on insiders to force it to make greater efforts to improve operational efficiency (Hart, 1983; Schmidt, 1997). If the managers' investment is inefficient of negative net present value, then the enterprise will eventually be out of the competitiveness of being expelled from the market, and the managers will be tragically eliminated, lost their jobs. The threat of bankruptcy liquidation allows managers to use cash more effectively. In the competitive product market, insiders who attempt to invade the shareholders' wealth for their own use, will inevitably lead to the hardship of the business (Fama, 1980).

Chhaochharia et al. (2017) study the relationship between market competition 
and internal governance mechanisms. The results show that product market competition can be used as an alternative to internal governance. After the adoption of the SOX bill, companies in concentrated industries are making greater improvements in operating efficiency than those in non-centralized industries. It shows product market competition as an effective corporate governance mechanism can ease the issue of principal-agent, and motivate managers to work hard. Moreover, it can inhibit managers to squander cash flow and help to improve the efficiency of the use of funds, as well as to improve business performance and increase corporate value. Therefore, from the agency point of view, in other conditions remain unchanged, the more intense product market competition, the higher the marginal value of the company's cash holdings.

\subsection{Product Market Competition, Predatory Threat and Value of Cash Holdings}

Tesler (1966), Bolton \& Scharfstein (1990) show that firms with strong finance will increase production and lower product prices to grab market share. Such predatory competition will force companies facing financing constraints into financial distress and eventually withdraw from the market. The limitations of external funds hinder the competitiveness of companies lacking of cash in the product market, in turn, to promote the company with great financial strength to implement the predatory behavior. Chevalier \& Scharfstein (1996) have shown that companies with insufficient cash holdings are less likely to invest in establishing market standings. In their model, the company directly decreases the price to obtain long-term market share, rather than taking the short-term profit maximization as a goal.

However, generally, cash holdings are often used for strategic investments rather than predatory pricing, such as capital expenditure, R\&D investment, network placement, plant location, advertising, staff recruitment and mergers of important suppliers or business partners and so on. All in all, these studies show that cash-rich companies will use these resources to support competitive strategies to improve their long-term performance in the product market. The indirect effect of cash is mainly on the impact of other competitors' behavior. For instance, the cash reserve can be seen as a weapon that can distort the competitor's strategy.

Fresard's (2010) shows that a large amount of cash reserves will increase the company's future product market share. It mainly because the company can use these reserves to provide support for strategic deployment, then the company can rely on its strong level of assets and liabilities, to use of pricing strategy to challenge the bottom card of the opponent. In addition, the company can also use cash reserves to do some competitive options such as choosing location for store or factory, efficient distribution network construction, advertising campaigns and even hiring efficient employee. By cash accumulation to competitors to demonstrate the possibility of radical behavior, thus distorting competitors' actions in the product market, cash holdings can be used as a pre-emptive strat- 
egy to influence competitors' entry and production capacity expansion decisions (Benoit, 1984).

In the imperfect capital market, external financing costs are higher than internal financing costs due to the existence of information asymmetry and agency problems. Hence the external and internal funds cannot be completely substituted (Fazzari et al., 1988). Enterprises do not always have access to funds at time in need, and have to give up valuable investment projects due to a lack of internal funds, resulting in insufficient investment, which eventually leads to the risk of predatory arising from the loss of investment opportunities and the market share taking by competitors. By increase cash holdings, enterprises can not only compete with competitors in the price and production, but also have strategic investment in various aspects. Therefore, from a strategic point of view, in other conditions remain unchanged, the higher the risk of predatory in the product market, the greater the marginal value of the company to increase. Haushalter et al. (2007) find inter- and intra-industry evidence that the extent of the interdependence of a firm's investment opportunities with rivals is positively associated with the size of its cash holdings. Alimov (2013) provide that the trade liberalization leads to a significant increase in the value of cash holdings for firms experiencing a larger shock to their competitive environment. Chi and $\mathrm{Su}$ (2016) find that the value of cash is significantly higher for firms facing higher predatory threats.

In our research, we check the relation between predatory risk and the finance behavior of corporations based on the empirical data of China. Moreover, compared to the effective markets in developed countries, China has an ineffective market and a special institutional environment, which may exert influence on the underlying relation.

\section{Design of Empirical Model}

\subsection{Data Sources}

We select China A-share listed companies from 2000 to 2013 as the sample space for empirical analysis. Sample should be 1) non-financial companies and 2) companies with negative operating income, but three sorts of companies are excluded. That is 3) companies of negative net assets (total assets minus cash holdings) and of negative book shareholders' equity, 4) companies with missing accounting indicators, and 5) excluding companies that have less than 12-month yield in a year.

In order to exclude the effect of extreme values on the conclusions, this paper deals with all the values of the variables with $99 \%$ winsorization, i.e., all data below the 1 th percentile set to the 1 th percentile, and data above the 99th percentile set to the 99th percentile.

The required financial data are from two Chinese databases, the China Stock Market \& Accounting Research (CSMAR) and Wind Information (Wind Info.). Furthermore, CSMAR Database offers data on the China stock markets and the 
financial statements of China's listed companies, and Wind Information is the market leader in China's financial data services industry, providing accurate and real-time fundamental data, exchange data, earnings estimate data, market data, and sophisticated communication platforms for financial professionals.

\subsection{Description and Measurement of Variables}

\subsubsection{Measurement of Predatory Risk of Product Market}

By applying the approach of Haushalter (2007), we use the Beta of industry to measure the interdependence of investment opportunities between the firm and its competitors. Since the company's stock price reflects the present value of future cash flows, the company's stock price is more sensitive to its competitors if the company shares a greater percentage of growth opportunities with its competitors. Industry Beta reflects this sensitivity, that is, if the industry beta is greater, the greater the interdependence between the company and its competitors, the higher the risk of predatory, and the more intense competition. We have

$$
r_{i, t}-R_{i, t}=\beta_{0}+\beta_{1} \cdot r_{\text {industry }, t}+\beta_{2} \cdot r_{m, t}+\varepsilon_{i, t} .
$$

where $r_{i, t}$ is the monthly yield rate of sampled company with consideration of dividend reinvestment, $r_{\text {industry, } t}$ is the average monthly yield rate of different industries, while the classification criteria is based on the Listed Companies Industry Classification Guidelines issued by China Securities Regulatory Commission in 2012. The variable $r_{m, t}$ is the weighted average of the A-share monthly yield rate with the total market capitalization. The estimate samples of the coefficients of regression model are using 36 to 60 months rolling data. The estimated coefficient $\beta_{1}$ used to measure the sensitivity of the yield of individual stocks to the yield of the industry. A higher $\beta_{1}$ value implicate a stronger interdependence of the company and the competitor, and a greater predatory risk and the more intense the product market competition.

To make the estimation results better explained, this paper divides $\beta_{1}$ into two groups according to the value of estimated $\beta_{1}$. We set the group with larger value of $\beta_{1}$ to be 1 , which implies a high risk of predatory, and set the group with smaller value of $\beta_{1}$ to be 0 , which indicates a lower risk of predatory.

\subsubsection{Measurement of Marginal Value of Cash Holdings}

We add the variables of product market competition into the model of Faulkender \& Wang (2006). The calculation process is as follows: According to the three-factor model of Fama \& French (1993), we estimate that the monthly cumulative excess return rate, then sum up to get the annual cumulative abnormal return (CAR). Fama \& French (1993) divide the company size and book-tomarket ratio $(\mathrm{B} / \mathrm{M})$ into 5 groups respectively, and construct 25 size-and-B/M investment portfolio. We choose the data of size of the company at June 30 of each year, and take the $\mathrm{B} / \mathrm{M}$ ratio at December 31 of each year.

To be specific, on the one hand, the size of the company is also known as the 
market value of company's equity, calculated by the closed stock price on the last work day of June times the total amount stock shares. All companies in sample are divided into five groups according to their size. On the other hand, rank the book-to-market ration from high to low and divide all companies in sample space into 5 groups. Then, by combing the two pairs of groups mutually, we have 25 benchmark portfolios, and each company finds its own benchmark portfolio. Furthermore, take the relative market value of a single stock (the ration of the market value of a stock and the total value of all stock in a group) for the weight, to find the weight average of monthly return of a stock from the July of $t$-th year to June of $t+1$-th year, then to obtain monthly benchmark portfolio returns. Finally, calculate the annual rate of return of each company relative to the benchmark portfolio with the return rate of the company's stock and the monthly return rate of benchmark portfolio, and then distract the benchmark portfolio return rate from the annual return rate for each company, to get the cumulative annual excess rate of return for each stock.

$$
\begin{aligned}
r_{i, t}-R_{i, t}= & \beta_{0}+\beta_{1} \frac{\Delta C_{i, t}}{M_{i, t-1}}+\beta_{2} \frac{\Delta C_{i, t-1}}{M_{i, t-1}} \cdot \frac{\Delta C_{i, t}}{M_{i, t-1}}+\beta_{3} L_{i, t} \frac{\Delta C_{i, t-1}}{M_{i, t-1}} \\
& +\beta_{4} \frac{\Delta E_{i, t}}{M_{i, t-1}}+\beta_{5} \frac{\Delta N A_{i, t}}{M_{i, t-1}}+\beta_{6} \frac{\Delta R D_{i, t}}{M_{i, t-1}}+\beta_{7} \frac{\Delta I_{i, t}}{M_{i, t-1}} \\
& +\beta_{8} \frac{\Delta D_{i, t}}{M_{i, t-1}}+\beta_{9} \frac{\Delta C_{i, t-1}}{M_{i, t-1}}+\beta_{10} L_{i, t}+\beta_{11} \frac{N F_{i, t}}{M_{i, t-1}}+\varepsilon_{i, t} .
\end{aligned}
$$

Here, $r_{i, t}$ is the company's stock return rate, $R_{i, t}$ is the company's benchmark portfolio return, $r_{i, t}-R_{i, t}$ is the company's annual cumulative stock excess return rate, $\Delta X_{i, t}$ indicates the change of variable $X$ of company $i$ from the time $t-1$ to time $t$. More specific, $C$ is the sum of the monetary and transactional financial assets; $E$ is the earnings before interest and tax plus depreciation and the amortization (EBITDA); $N A$ is the non-cash asset, i.e., the total assets minus the monetary funds and trading financial assets; $R D$ is the research and development expenditure, if the data is missing, the value is 0 ; $I$ is the interest expense; $D$ is the total amount of cash dividends; $L$ is the market value leverage level, calculated by dividing liabilities with interests with the sum of liabilities with interests and equity value; $N F$ is the annual net financing, which is equal to the newly issued shares and bonds plus the new borrower minus the repayment; and $M$ is the market value of equity. All notations are summarized in Table 1.

Then we have

$$
M \hat{V} C=\hat{\lambda}_{1}+\hat{\lambda}_{2} \frac{C_{i, t-1}}{M_{i, t-1}}+\hat{\lambda}_{3} L_{i, t}
$$

Here, $M \hat{V} C$ is the marginal value of cash holdings, and $\hat{\lambda}_{i}, i=1,2,3$ are coefficients.

Based on (2), we add the product market competition, and the cross item of product market competition and cash increment, we have 
Table 1. Notations.

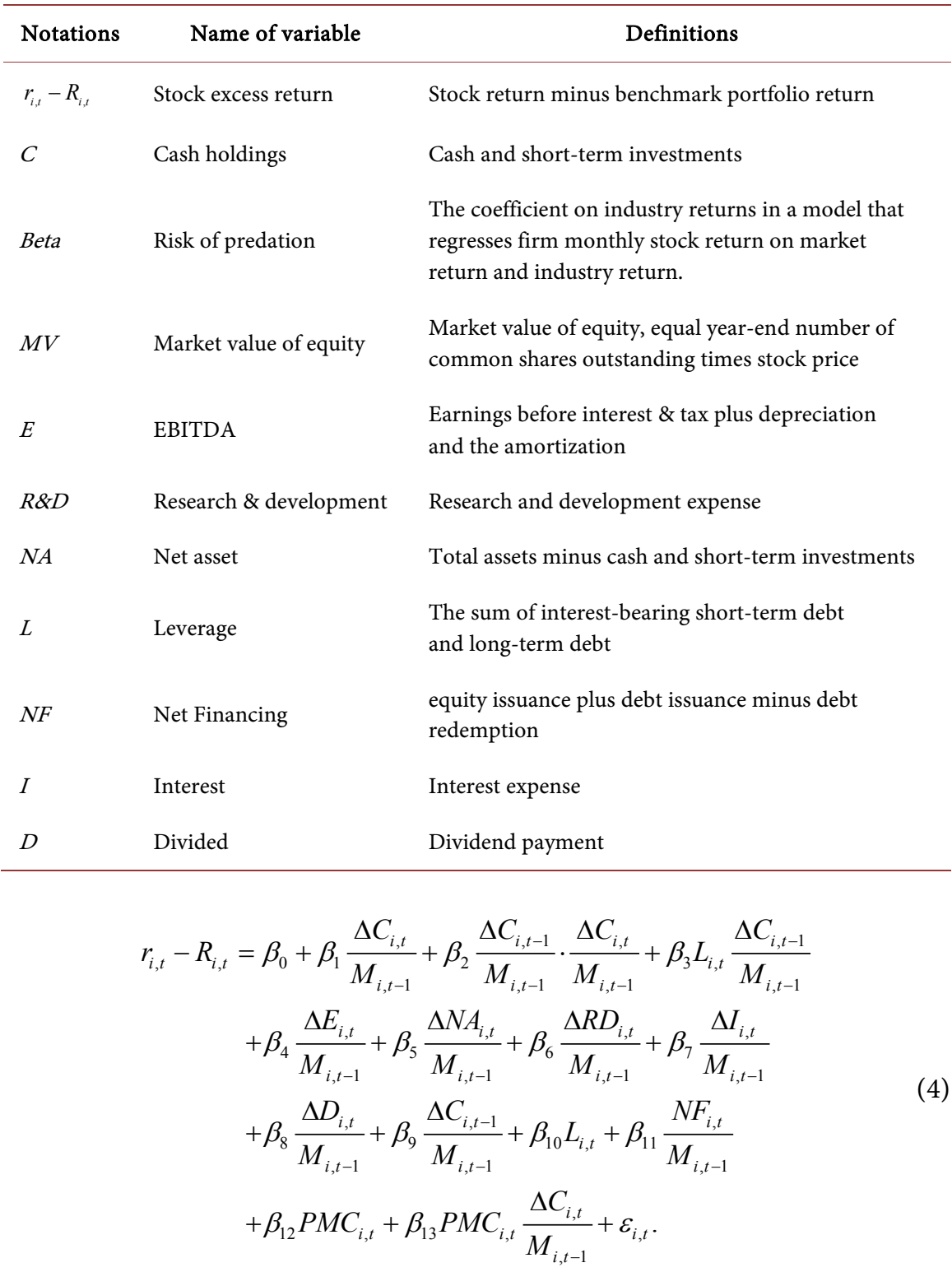

Then, we apply regression analysis to the sample data using the Equation (4). After estimating the result, the marginal value of cash holdings becomes

$$
M \hat{V C}=\hat{\beta}_{1}+\hat{\beta}_{2} \frac{C_{i, t-1}}{M_{i, t-1}}+\hat{\beta}_{3} L_{i, t}+\beta_{13} P M C_{i, t} .
$$

The impact of predatory risk on the marginal value of cash holdings is reflected in the term $\beta_{13} P M C$. Since $P M C$ is a $0-1$ variable, specifically, if the risk of predatory is high, the product market threat is large, then set the $P M C$ to be 1 ; otherwise, take $P M C$ to be 0 . The impact of the risk of predatory on the marginal value of cash holdings is reflected in the significance level and size of the estimated parameter $\hat{\beta}_{3}$. If $\hat{\beta}_{3}>0$, then a threaten risk in product market increase the marginal value of cash holdings. If $\hat{\beta}_{3}<0$, then a threaten risk in product market decrease the marginal value of cash holdings. 


\section{Results and Analysis}

\subsection{Descriptive Statistics}

We use Stata 12 to collect the sample description statistics in Table 2, the average excess return of sample listed companies is -0.011 and the standard deviation is 0.429 , which indicates that there is a great difference in the excess return rate of listed companies in China. The average of the industry Beta is 0.966 and the standard deviation is 0.579 , which indicates that there are large differences in the risk of predatory in China.

Moreover, the average cash holdings are 0.15; the average market leverage is 0.219 ; the average cash holdings change is 0.014 ; the average EBIT change is 0.011 ; the average net asset change is 0.113 ; the average market value is 0.113 ; the change in $\mathrm{R} \& \mathrm{D}$ expenditure is 0.001 for the lagged market value. The average cash dividend payout is $0.001 \%$ of the lagged market value. The average interest payment is 0.002 , and the average annual net financing is 0.055 .

\subsection{Results}

\subsubsection{Excess Returns Based on the Fama-French Benchmark Portfolio}

To ensure the conclusions are more robust and reliable, this paper uses the mixed ordinary least square (OLS) regression, the OLS regression with industry and year controlled, and fixed effect (FE) method of panel data to estimate equation (4). The results are shown in Table 3.

From the results shown in Table 3, the coefficient of the cross-term of the lagged cash and the cash change is not significant; but the coefficient of the cross-term of the financial leverage and cash changes are significantly negative at the $1 \%$ level, indicating that in other variables remain unchanged, the value adding of a company by increasing in cash holdings largely fall into the hands of creditors. As the financial leverage increases, the marginal value of the company's cash holdings decreases.

Table 2. Descriptive statistics.

\begin{tabular}{ccccccc}
\hline & Mean & SD & $5 \%$ th & Median & $75 \%$ th & Observations \\
\hline$r_{i, t}-R_{i, t}$ & -0.011 & 0.429 & -0.204 & -0.059 & 0.117 & 14860 \\
$\Delta C_{i, t}$ & 0.0138 & 0.087 & -0.024 & 0.003 & 0.0372 & 14860 \\
Beta & 0.966 & 0.579 & 0.671 & 0.960 & 1.225 & 14860 \\
$\Delta E_{i, t}$ & 0.011 & 0.058 & -0.007 & 0.006 & 0.023 & 14860 \\
$\Delta N A_{i, t}$ & 0.113 & 0.217 & 0.005 & 0.059 & 0.158 & 14860 \\
$\Delta R D_{i, t}$ & 0.001 & 0.005 & 0.000 & 0.000 & 0.000 & 14860 \\
$\Delta I_{i, t}$ & 0.002 & 0.009 & -0.001 & 0.000 & 0.004 & 14860 \\
$\Delta D_{i, t}$ & 0.001 & 0.009 & -0.001 & 0.000 & 0.002 & 14860 \\
$C_{i, t-1}$ & 0.150 & 0.138 & 0.056 & 0.108 & 0.199 & 14860 \\
$L_{i, t}$ & 0.219 & 0.180 & 0.072 & 0.176 & 0.334 & 14860 \\
$N F_{i, t}$ & 0.055 & 0.131 & -0.005 & 0.015 & 0.082 & 14860 \\
\hline
\end{tabular}


Table 3. Product market competition and marginal value of cash holdings: Fama-French Benchmark Portfolio.

\begin{tabular}{|c|c|c|c|c|c|c|}
\hline & Pool OLS & Pool OLS & $\mathrm{FE}$ & $\mathrm{FE}$ & Panel FE & Panel FE \\
\hline$\Delta C_{i, t}$ & $\begin{array}{c}0.732^{* * *} \\
(9.19)\end{array}$ & $\begin{array}{c}0.617^{* * *} \\
(6.55)\end{array}$ & $\begin{array}{c}0.970^{* * *} \\
(12.04)\end{array}$ & $\begin{array}{c}0.848^{* * *} \\
(8.59)\end{array}$ & $\begin{array}{c}1.109^{* * *} \\
(12.82)\end{array}$ & $\begin{array}{c}0.969^{* * *} \\
(9.57)\end{array}$ \\
\hline$C_{i, t-1} \Delta C_{i, t}$ & $\begin{array}{l}0.228 \\
(1.11)\end{array}$ & $\begin{array}{l}0.253 \\
(1.23)\end{array}$ & $\begin{array}{l}0.021 \\
(0.10)\end{array}$ & $\begin{array}{l}0.048 \\
(0.24)\end{array}$ & $\begin{array}{l}-0.031 \\
(-0.14)\end{array}$ & $\begin{array}{l}0.011 \\
(0.05)\end{array}$ \\
\hline$L_{i, t} \Delta C_{i, t}$ & $\begin{array}{c}-1.445^{* * *} \\
(-7.20)\end{array}$ & $\begin{array}{c}-1.423^{* * *} \\
(-7.09)\end{array}$ & $\begin{array}{c}-1.693^{* * *} \\
(-8.47)\end{array}$ & $\begin{array}{c}-1.667^{* * *} \\
(-8.34)\end{array}$ & $\begin{array}{c}-1.523^{* * *} \\
(-7.14)\end{array}$ & $\begin{array}{c}-1.493^{* * *} \\
(-7.00)\end{array}$ \\
\hline$\Delta E_{i, t}$ & $\begin{array}{c}1.335^{* * *} \\
(21.02)\end{array}$ & $\begin{array}{l}1.331^{* * *} \\
(20.99)\end{array}$ & $\begin{array}{l}1.522^{* * *} \\
(23.70)\end{array}$ & $\begin{array}{c}1.520^{* * *} \\
(23.7)\end{array}$ & $\begin{array}{l}1.360^{* * *} \\
(20.84)\end{array}$ & $\begin{array}{c}1.358^{* * *} \\
(20.82)\end{array}$ \\
\hline$\Delta N A_{i, t}$ & $\begin{array}{c}0.220^{* * *} \\
(10.37)\end{array}$ & $\begin{array}{c}0.220^{* * *} \\
(10.48)\end{array}$ & $\begin{array}{c}0.253^{* * *} \\
(11.90)\end{array}$ & $\begin{array}{c}0.255^{* * *} \\
(12.01)\end{array}$ & $\begin{array}{c}0.225^{* * *} \\
(10.05)\end{array}$ & $\begin{array}{c}0.224^{* * *} \\
(10.0)\end{array}$ \\
\hline$\Delta R D_{i, t}$ & $\begin{array}{c}2.433^{* * *} \\
(3.91)\end{array}$ & $\begin{array}{c}2.408^{* * *} \\
(3.88)\end{array}$ & $\begin{array}{c}3.387^{* * *} \\
(5.25)\end{array}$ & $\begin{array}{c}3.402^{* * *} \\
(5.28)\end{array}$ & $\begin{array}{c}3.290^{* * *} \\
(4.74)\end{array}$ & $\begin{array}{c}3.290^{* * *} \\
(4.74)\end{array}$ \\
\hline$\Delta I_{i, t}$ & $\begin{array}{l}0.235 \\
(0.55)\end{array}$ & $\begin{array}{l}0.227 \\
(0.54)\end{array}$ & $\begin{array}{c}-1.043^{* *} \\
(-2.37)\end{array}$ & $\begin{array}{c}-1.057^{* *} \\
(-2.41)\end{array}$ & $\begin{array}{l}-0.468 \\
(-1.03)\end{array}$ & $\begin{array}{l}-0.497 \\
(-1.1)\end{array}$ \\
\hline$\Delta D_{i, t}$ & $\begin{array}{c}3.029^{* * *} \\
(8.32)\end{array}$ & $\begin{array}{c}3.066^{* * *} \\
(8.42)\end{array}$ & $\begin{array}{c}2.706^{* * *} \\
(7.47)\end{array}$ & $\begin{array}{c}2.743^{* * *} \\
(7.57)\end{array}$ & $\begin{array}{c}1.939^{* * *} \\
(5.26)\end{array}$ & $\begin{array}{c}1.933^{* * *} \\
(5.25)\end{array}$ \\
\hline$C_{i, t-1}$ & $\begin{array}{c}0.238^{* * *} \\
(9.00)\end{array}$ & $\begin{array}{c}0.244^{* * *} \\
(9.22)\end{array}$ & $\begin{array}{c}0.440^{* * *} \\
(15.16)\end{array}$ & $\begin{array}{c}0.447^{* * *} \\
(15.43)\end{array}$ & $\begin{array}{c}0.896^{* * *} \\
(21.78)\end{array}$ & $\begin{array}{c}0.895^{* * *} \\
(21.77)\end{array}$ \\
\hline$L_{i, t}$ & $\begin{array}{c}-0.452^{\star * *} \\
(-21.29)\end{array}$ & $\begin{array}{c}-0.452^{\star * \star} \\
(-21.31)\end{array}$ & $\begin{array}{c}-0.627^{\star * *} \\
(-25.95)\end{array}$ & $\begin{array}{c}-0.627^{\text {}}(-25.99)\end{array}$ & $\begin{array}{c}-1.052^{* \star *} \\
(-29.18)\end{array}$ & $\begin{array}{c}-1.052^{\star * *} \\
(-29.21)\end{array}$ \\
\hline$N F_{i, t}$ & $\begin{array}{l}0.009 \\
(0.25)\end{array}$ & $\begin{array}{l}0.013 \\
(0.37)\end{array}$ & $\begin{array}{c}0.095^{* *} \\
(2.59)\end{array}$ & $\begin{array}{c}0.100^{* * *} \\
(2.73)\end{array}$ & $\begin{array}{c}0.085^{* *} \\
(2.18)\end{array}$ & $\begin{array}{c}0.092^{\star *} \\
(2.37)\end{array}$ \\
\hline$P M C_{i, t}$ & & $\begin{array}{c}0.029^{* * *} \\
(4.33)\end{array}$ & & $\begin{array}{c}0.031^{* * *} \\
(4.65)\end{array}$ & & $\begin{array}{c}0.037^{* * *} \\
(4.29)\end{array}$ \\
\hline$P M C_{i, t} \Delta C_{i, t}$ & & $\begin{array}{c}0.213^{* *} \\
(2.32)\end{array}$ & & $\begin{array}{c}0.227^{* *} \\
(2.50)\end{array}$ & & $\begin{array}{c}0.248^{* * *} \\
(2.57)\end{array}$ \\
\hline Industry effect & NO & NO & Yes & Yes & NO & $\mathrm{NO}$ \\
\hline Year effect & NO & $\mathrm{NO}$ & Yes & Yes & Yes & Yes \\
\hline Observations & 14860 & 14860 & 14381 & 14381 & 14860 & 14860 \\
\hline $\mathrm{R}$-square & $12.17 \%$ & $12.31 \%$ & $16.52 \%$ & $16.69 \%$ & $18.15 \%$ & $18.33 \%$ \\
\hline
\end{tabular}

Note: Robust standard errors are reported in parentheses; ${ }^{* * *}$, **, * indicate significant levels at $1 \%, 5 \%$, and $10 \%$, respectively.

In the absence of product market competition and the cross-term of product market competition and cash changes, we apply three different estimate approaches, the Pool OLS, the OLS with controlling industry and year effects, and panel data models with time and individual fixed effects, to obtain marginal value of cash holdings. Results are quite different, and the estimated results are $0.416,0.599$ and 0.775 , respectively. In such case, it shows that the cross-term is significantly positive at the $5 \%$ level, indicating that the product market competition improves the marginal value of the company's cash holdings. Specifically, compared to companies that do not facing fierce competition in the product market, product market competition makes the company's cash margin value 
increased by 0.2 yuan. The marginal values of cash holdings obtained from three approaches are $0.518,0.710$ and 0.890 , respectively.

\subsubsection{Excess Return Based on Integrated Market Returns}

The Fama-French benchmark portfolio return is based on the data of the developed countries, while China's capital market is relative immature. The number of listed companies is relatively small, which to some extent affect the FamaFrench combination method in China's applicability. Therefore, in the calculation of excess return for each stock, in addition to use the Fama-French portfolio to adjust the stock return, we also use the integrated market returns to adjust the stock return. The regression results are shown in Table 4.

Table 4. Product market competition and marginal value of cash holdings: Based on integrated market returns

\begin{tabular}{|c|c|c|c|c|c|c|}
\hline & Pool OLS & Pool OLS & FE & FE & Panel FE & Panel FE \\
\hline$\Delta C_{i, t}$ & $\begin{array}{c}1.353^{* * *} \\
(15.38)\end{array}$ & $\begin{array}{c}1.118^{* * *} \\
(18.42)\end{array}$ & $\begin{array}{c}1.040^{* * *} \\
(12.65)\end{array}$ & $\begin{array}{c}0.898^{* * *} \\
(9.31)\end{array}$ & $\begin{array}{c}1.241^{* * *} \\
(14.04)\end{array}$ & $\begin{array}{c}1.083^{* * *} \\
(9.57)\end{array}$ \\
\hline$C_{i, t-1} \Delta C_{i, t}$ & $\begin{array}{l}-0.287 \\
(-1.27)\end{array}$ & $\begin{array}{l}-0.252 \\
(-1.11)\end{array}$ & $\begin{array}{l}-0.243 \\
(-1.17)\end{array}$ & $\begin{array}{l}-0.214 \\
(-1.03)\end{array}$ & $\begin{array}{l}-0.298 \\
(-1.34)\end{array}$ & $\begin{array}{l}-0.251 \\
(-1.13)\end{array}$ \\
\hline$L_{i, t} \Delta C_{i, t}$ & $\begin{array}{c}-2.148^{* * *} \\
(-9.69)\end{array}$ & $\begin{array}{c}-2.114^{* * *} \\
(-9.55)\end{array}$ & $\begin{array}{c}-1.546^{* * *} \\
(-7.58)\end{array}$ & $\begin{array}{c}-1.514^{* * *} \\
(-7.44)\end{array}$ & $\begin{array}{c}-1.457^{* * *} \\
(-6.69)\end{array}$ & $\begin{array}{c}-1.421^{* * *} \\
(-6.53)\end{array}$ \\
\hline$\Delta E_{i, t}$ & $\begin{array}{c}1.553^{\star * *} \\
(22.13)\end{array}$ & $\begin{array}{c}1.547^{* * *} \\
(22.09)\end{array}$ & $\begin{array}{c}1.520^{* * *} \\
(23.35)\end{array}$ & $\begin{array}{c}1.527^{\star * *} \\
(23.36)\end{array}$ & $\begin{array}{c}1.356^{\star * *} \\
(20.34)\end{array}$ & $\begin{array}{c}1.353^{\star * *} \\
(20.32)\end{array}$ \\
\hline$\Delta N A_{i, t}$ & $\begin{array}{c}0.233^{* * *} \\
(9.69)\end{array}$ & $\begin{array}{c}0.236^{* * *} \\
(10.13)\end{array}$ & $\begin{array}{c}0.220^{* * *} \\
(10.18)\end{array}$ & $\begin{array}{c}0.224^{* * *} \\
(10.38)\end{array}$ & $\begin{array}{c}0.207^{* * *} \\
(9.07)\end{array}$ & $\begin{array}{c}0.207^{* * *} \\
(9.04)\end{array}$ \\
\hline$\Delta R D_{i, t}$ & $\begin{array}{c}2.433^{\star * *} \\
(3.91)\end{array}$ & $\begin{array}{c}3.932^{\star * *} \\
(5.74)\end{array}$ & $\begin{array}{c}3.396^{* * *} \\
(5.16)\end{array}$ & $\begin{array}{c}3.342^{\star * *} \\
(5.22)\end{array}$ & $\begin{array}{c}3.623^{* \star *} \\
(5.10)\end{array}$ & $\begin{array}{c}3.628^{\star * *} \\
(5.12)\end{array}$ \\
\hline$\Delta I_{i, t}$ & $\begin{array}{l}0.235 \\
(0.55)\end{array}$ & $\begin{array}{l}0.235 \\
(0.55)\end{array}$ & $\begin{array}{l}-0.572 \\
(-1.28)\end{array}$ & $\begin{array}{l}-0.585 \\
(-1.31)\end{array}$ & $\begin{array}{l}0.068 \\
(0.15)\end{array}$ & $\begin{array}{c}0.035 \\
(0.08)\end{array}$ \\
\hline$\Delta D_{i, t}$ & $\begin{array}{c}-4.377^{\star * *} \\
(9.35)\end{array}$ & $\begin{array}{c}-4.384^{\star * \star} \\
(-9.38)\end{array}$ & $\begin{array}{c}2.900^{* * *} \\
(7.85)\end{array}$ & $\begin{array}{c}2.956^{\star * *} \\
(8.01)\end{array}$ & $\begin{array}{c}2.354^{* \star *} \\
(6.25)\end{array}$ & $\begin{array}{c}2.343^{\star * *} \\
(6.23)\end{array}$ \\
\hline$C_{i, t-1}$ & $\begin{array}{c}0.493^{* * *} \\
(16.88)\end{array}$ & $\begin{array}{c}0.503^{* * *} \\
(17.26)\end{array}$ & $\begin{array}{c}0.528^{* * *} \\
(17.85)\end{array}$ & $\begin{array}{c}0.541^{* * *} \\
(18.31)\end{array}$ & $\begin{array}{c}1.040^{* * *} \\
(24.73)\end{array}$ & $\begin{array}{c}1.038^{* * *} \\
(24.72)\end{array}$ \\
\hline$L_{i, t}$ & $\begin{array}{c}-0.835^{\star * *} \\
(-35.60)\end{array}$ & $\begin{array}{c}-0.835^{\star * \star} \\
(-35.69)\end{array}$ & $\begin{array}{c}-0.732^{\star * *} \\
(-29.74)\end{array}$ & $\begin{array}{c}-0.733^{\star * *} \\
(-29.84)\end{array}$ & $\begin{array}{c}-1.234^{* \star \star} \\
(-33.49)\end{array}$ & $\begin{array}{c}-1.235^{\star * *} \\
(-33.56)\end{array}$ \\
\hline$N F_{i, t}$ & $\begin{array}{c}0.256^{* * *} \\
(6.37)\end{array}$ & $\begin{array}{c}0.264^{* * *} \\
(6.57)\end{array}$ & $\begin{array}{c}0.124^{* * *} \\
(3.33)\end{array}$ & $\begin{array}{c}0.133^{* * *} \\
(3.56)\end{array}$ & $\begin{array}{c}0.125^{* * *} \\
(3.13)\end{array}$ & $\begin{array}{c}0.134^{* *} \\
(3.37)\end{array}$ \\
\hline$P M C_{i, t}$ & & $\begin{array}{c}0.052^{* \star *} \\
(7.09)\end{array}$ & & $\begin{array}{c}0.053^{\star * *} \\
(7.73)\end{array}$ & & $\begin{array}{c}0.050^{\star * *} \\
(5.64)\end{array}$ \\
\hline$P M C_{i, t} \Delta C_{i, t}$ & & $\begin{array}{c}0.310^{* * *} \\
(3.06)\end{array}$ & & $\begin{array}{c}0.267^{* * *} \\
(2.88)\end{array}$ & & $\begin{array}{c}0.279^{* * *} \\
(2.83)\end{array}$ \\
\hline Industry effect & NO & NO & Yes & Yes & NO & NO \\
\hline Year effect & $\mathrm{NO}$ & NO & Yes & Yes & Yes & Yes \\
\hline Observations & 14860 & 14860 & 14381 & 14381 & 14860 & 14860 \\
\hline $\mathrm{R}$-square & $20.05 \%$ & $20.40 \%$ & $35.42 \%$ & $35.75 \%$ & $38.08 \%$ & $38.29 \%$ \\
\hline
\end{tabular}

Note: Robust standard errors are reported in parentheses; ${ }^{* *},{ }^{* *},{ }^{*}$ indicate significant levels at $1 \%, 5 \%$, and $10 \%$, respectively. 
From the Table 4, the correlation coefficient of the lagged cash and the change of cash holdings is not significant, but the correlation of the financial leverage and the change of cash holdings is significantly negative at the $1 \%$ level, indicating that in other cases remain the same, with the increase in financial leverage, the marginal value of the company's cash holdings decreases.

In the absence of product market competition and the cross-term of product market competition and cash changes, we apply three different estimate approaches, the Pool OLS, the LOS with controlling industry and year effects, and panel data models with time and individual fixed effects, to obtain marginal value of cash holdings. Results are quite different, the marginal value are 0.883 , 0.701 and 0.922 , respectively. In such case, it shows that the cross-term is significantly positive at the $5 \%$ level, indicating that the product market competition improves the marginal value of the company's cash holdings. Specifically, compared to companies that do not facing fierce competition in the product market, product market competition makes the company's cash margin value increased by 0.3 yuan. The marginal values of cash holdings obtained from three approaches are $0.965,0.833$ and 1.051 , respectively.

\section{Conclusion}

In previous study of cash holdings theory, scholars usually focus on company's characteristics, corporate governance and so on. As an important external governance mechanism, the product market competition can reduce the agency conflict and play a strategic role in the company development, and will inevitably affect the marginal value of cash holdings.

Instead of studying the marginal value of cash holdings from the internal characteristics of the company, we focus on the external mechanism from the product market competition to explore the company's cash holdings marginal value, and further expand the research content and scope of cash holdings issue. Based on the sample of A-share listed companies in China from 2000 to 2013, the research shows that the risk of predatory in the product market increases the marginal value of cash holdings, and it increases the marginal value of cash holdings by about 0.2 Yuan.

In addition, the study also finds that, in other cases remain unchanged, with the increase in financial leverage, the marginal value of the company's cash holdings will reduce. And there is no evidence that the amount of cash holdings has an impact on the marginal value of the company's cash holdings.

Due to China's special institutional background, state-owned enterprises may have soft budget constraints. For China's credit market, the government has a decisive influence on the allocation of credit resources (Fang, 2007). In most cases, the government has the right to decide which companies to provide loans. Hence more credit funds are provided to state-owned enterprises or closely related companies ( $\mathrm{Li}$ et al., 2009; Fang, 2007). Whether this relationship will weaken the relationship between the predation risk and the value of cash holding is worth for further study. In addition, we can draw on the methodology of Ho- 
berg \& Maksimovic (2014) to analyze the financial report based on the computer linguistics method to construct the index of market liquidity, then to explore more accurately the relationship between the risk of predation and the value of cash holdings.

\section{References}

Alimov, A. (2013). Product Market Competition and the Value of Corporate Cash: Evidence from Trade Liberalization. Journal of Corporate Finance, 25, 122-139.

Bates, T. W., Chang, C. H., \& Chi, J. D., (2017). Why Has the Value of Cash Increased over Time? Journal of Financial and Quantitative Analysis.

Benoit, J. P. (1984). Financially Constrained Entry in a Game with Incomplete Information. The RAND Journal of Economics, 15, 490-499. https://doi.org/10.2307/2555520

Bolton, P., \& Scharfstein, D. S. (1990). A Theory of Predation Based on Agency Problems in Financial Contracting. American Economic Review, 80, 93-106.

Chevalier, J. A., \& Scharfstein, D. S. (1996). Capital-Market Imperfections and Countercyclical Markups: Theory and Evidence. American Economic Review, 86, 703-715.

Chhaochharia, V., Grinstein, Y., Grullon G., \& Michaely, R. (2017). Product Market Competition and Internal Governance: Evidence from the Sarbanes-Oxley Act. Management Science, 63, 1405-1424. https://doi.org/10.1287/mnsc.2015.2409

Chi, J. D., \& Su, X. H. (2016). Product Market Predatory Threats and the Value of Cash Holdings. Financial Management, 3, 705-735. https://doi.org/10.1111/fima.12119

Fama, E. F. (1980). Agency Problems and the Theory of the Firm. Journal of Political Economy, 88, 288-307. https://doi.org/10.1086/260866

Fama, E. F., \& French, K. R. (1993). Common Risk Factors in the Returns on Stocks and Bonds. Journal of Financial Economics, 33, 3-56.

Fang, J. (2007). Ownership, Institutional Environment and Capital Allocation. Economic Research Journal, 12, 82-92. (In Chinese)

Faulkender, M., \& Wang, R. (2006). Corporate Financial Policy and the Value of Cash. The Journal of Finance, 61, 1957-1990. https://doi.org/10.1111/j.1540-6261.2006.00894.x

Fazzari, S. M., Hubbard, R. G., Petersen, B. C., Blinder, A. S., \& Poterba, J. M. (1988). Financing Constraints and Corporate Investment. Brookings Papers on Economic Activity, 1, 141-206. https://doi.org/10.2307/2534426

Fresard, L. (2010). Financial Strength and Product Market Behavior: The Real Effects of Corporate Cash Holdings. Journal of Finance, 65, 1097-1122.

https://doi.org/10.1111/j.1540-6261.2010.01562.x

Hart, O. (1983). The Market as an Incentive Mechanism. Bell Journal of Economics, 14, 366-382. https://doi.org/10.2307/3003639

Haushalter, D., Klasa, S., \& Maxwell, W. F. (2007). The Influence of Product Market Dynamics on a Firm's Cash Holdings and Hedging Behavior. Journal of Financial Economics, 84, 797-825.

Hoberg, G., \& Maksimovic, V. (2014). Redefining Financial Constraints: A Text-Based Analysis. Review of Financial Studies, 28, 1312-1352.

https://doi.org/10.1093/rfs/hhu089

Li, K., Yue, H., \& Zhao, L. (2009). Ownership, Institutions, and Capital Structure: Evidence from China. Journal of Comparative Economics, 37, 471-490.

Schmidt, K. M. (1997). Managerial Incentives and Product Market Competition. Review 
of Economic Studies, 64, 191-213. https://doi.org/10.2307/2971709

Tesler, L. G. (1966). Cut Throat Competition and the Long Purse. Journal of Law and Economics, 9, 259-277. https://doi.org/10.1086/466627

\section{Scientific Research Publishing}

Submit or recommend next manuscript to SCIRP and we will provide best service for you:

Accepting pre-submission inquiries through Email, Facebook, LinkedIn, Twitter, etc. A wide selection of journals (inclusive of 9 subjects, more than 200 journals)

Providing 24-hour high-quality service

User-friendly online submission system

Fair and swift peer-review system

Efficient typesetting and proofreading procedure

Display of the result of downloads and visits, as well as the number of cited articles Maximum dissemination of your research work

Submit your manuscript at: http://papersubmission.scirp.org/

Or contact jfrm@scirp.org 